University of Wollongong

Research Online

Faculty of Business - Papers (Archive)

Faculty of Business and Law

$1-1-2014$

What happens when digital information systems are brought into health and social care? Comparing approaches to social policy in England and Australia

Susan Baines

Manchester Metropolitan University

Penelope Hill

Mortimore Hill Associates

Karin Garrety

University of Wollongong, karin@uow.edu.au

Follow this and additional works at: https://ro.uow.edu.au/buspapers

Part of the Business Commons

Research Online is the open access institutional repository for the University of Wollongong. For further information contact the UOW Library: research-pubs@uow.edu.au 


\title{
What happens when digital information systems are brought into health and social care? Comparing approaches to social policy in England and Australia
}

\begin{abstract}
This review article offers a brief comparative overview of approaches to the application of public sector information systems in England and Australia, with particular reference to health and social care. Since the 1990s, reforms to the public sector in both countries have looked to information and communication technologies (ICTs) from the private sector as the key to modern, citizen-centred services. These efforts have been conducted in the wider context of New Public Management, with the emphasis on the marketisation of government services, reducing the size of the state, and improvements in efficiency. Both countries are typically seen as being at, or near, the forefront of the digital transformation of public services (United Nations, 2012; McLoughlin and Wilson, 2013). Moreover, there is a shared history of experimentation, most recently in the shaping of the information agendas around records and personalisation.
\end{abstract}

\section{Keywords}

systems, england, brought, into, health, policy, social, care, comparing, approaches, happens, when, australia, digital, information

\section{Disciplines \\ Business}

\section{Publication Details}

Baines, S., Hill, P. \& Garrety, K. (2014). What happens when digital information systems are brought into health and social care? Comparing approaches to social policy in England and Australia. Social Policy and Society, 13 (4), 569-578. 


\section{Social Policy and Society}

http://journals.cambridge.org/SPS

Additional services for Social Policy and Society:

Email alerts: $\underline{\text { Click here }}$

Subscriptions: $\underline{\text { Click here }}$

Commercial reprints: $\underline{\text { Click here }}$

Terms of use : $\underline{\text { Click here }}$

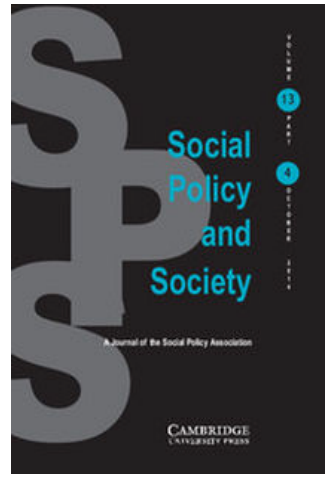

\section{What Happens When Digital Information Systems Are Brought Into Health and Social Care? Comparing Approaches to Social Policy in England and Australia}

Susan Baines, Penelope Hill and Karin Garrety

Social Policy and Society / Volume 13 / Issue 04 / October 2014, pp 569 - 578

DOI: 10.1017/S1474746414000256, Published online: 26 June 2014

Link to this article: http://journals.cambridge.org/abstract_S1474746414000256

How to cite this article:

Susan Baines, Penelope Hill and Karin Garrety (2014). What Happens When Digital Information Systems Are Brought Into Health and Social Care? Comparing Approaches to Social Policy in England and Australia. Social Policy and Society, 13, pp 569-578 doi:10.1017/

S1474746414000256

Request Permissions : $\underline{\text { Click here }}$ 


\title{
Review Article
}

\section{What Happens When Digital Information Systems Are Brought Into Health and Social Care? Comparing Approaches to Social Policy in England and Australia}

\author{
Susan Baines*, Penelope Hill** and Karin Garrety*** \\ *The Centre for Enterprise, Manchester Metropolitan University \\ E-mail: s.baines@mmu.ac.uk \\ ** Mortimore Hill Associates, Churcham, Gloucestershire \\ E-mail:p.hill@mortimorehill.co.uk \\ ***School of Management and Marketing, University of Wollongong \\ E-mail: karin@uow.edu.au
}

\section{Introduction}

This review article offers a brief comparative overview of approaches to the application of public sector information systems in England and Australia, with particular reference to health and social care. Since the 1990s, reforms to the public sector in both countries have looked to information and communication technologies (ICTs) from the private sector as the key to modern, citizen-centred services. These efforts have been conducted in the wider context of New Public Management, with the emphasis on the marketisation of government services, reducing the size of the state, and improvements in efficiency. Both countries are typically seen as being at, or near, the forefront of the digital transformation of public services (United Nations, 2012; McLoughlin and Wilson, 2013). Moreover, there is a shared history of experimentation, most recently in the shaping of the information agendas around records and personalisation.

We interrogate aspects of the recent history of each country to assess the strength and limitations of policy-making processes, understandings of information and expectations of technology.

\section{England: the joining up problem}

The Labour government, elected in 1997, instigated a far-reaching modernisation agenda for public services, with ICT as a central plank. The Modernising Government White Paper set out three core aims: delivering high-quality, efficient public services; ensuring that policy making was joined up and strategic; and making public services focus on users, not providers (Cabinet Office, 1999). Prime Minister Tony Blair pledged that 100 per cent of public services would, where possible, be made available electronically by 2005. The promise of e-government, later renamed 'transformational government', was integrated public services focussed around individual citizens, with ICT as the key enabler (Cabinet Office, 2005). An e-government programme for local government, 
funded to the tune of $£ 80$ million, was led by the Office of the Deputy Prime Minister, with twenty-three different projects aiming to ensure that all local authorities across England would have access to digital services (Cornford et al., 2003). In contrast, the much more ambitious long-term strategy for health was implemented through a large-scale national development project. The National Programme for Information Technology for Health (NPfIT) was established in 2002 to create an infrastructure for standard, inter-operable systems. The following year contracts worth $£ 6.2$ billion were awarded to a small number of consortia to develop and implement standard systems, some nationally and some by local service providers (McLoughlin and Wilson, 2013).

When e-government was launched at the end of the twentieth century, information technology systems were not, of course, entirely new in health or social care. They had existed across the UK since the 1960s, originally serving mainly as administrative tools supporting the production of statutory returns to government (Ames, 1999). Client indexes began to appear in the 1970s, and specialist 'stand alone' databases were developed for specific services in the 1980s. From the late 1980s, individual and local projects explored the support of frontline practice in both health and social care to varying degrees, and learning could be found by reference to similar projects undertaken in the USA (McCoy and Vila, 2002) and in Europe (Steyaert and Gould, 1999; Haux et al., 2002).

The publication in 2001 of Information for Social Care formally recognised that information was a fundamental and crucial element in the delivery of quality social care services (Social Care Information Policy Unit, 2001). The same year saw the launch of the National Service Framework for Older People, developed to raise standards in the way that services were provided for older people as individuals (Department of Health, 2001). Implementation of the Single Assessment Process (SAP) followed at local level, aiming to help deliver on the framework's promise of more person-centred care. SAPs were intended to provide a common approach to sharing information, thereby improving coordination, referral and discharge between the different parts of the care network. They could be implemented either as a set of paper-based or computer-based forms (Wilson et al., 2007).

For children's services, major reforms were set out in the Green Paper, Every Child Matters (Department for Education and Skills, 2003). The Green Paper was published alongside the formal response into the report into the death of Victoria Climbié. This high profile case of an eight-year old killed by her carers in London in 2001 was cited in the Green Paper as an extreme instance of failure on the part of social care, health and other agencies to share the information they separately held. The Children Act, which followed in 2004, legislated for integrated education, childcare, health and social care, and more effective interplay between universal and specialist services. ICT programmes driven by outcomes related to Every Child Matters included structured assessment forms and, most controversially, a national database of all children and young people known as ContactPoint.

Initiatives to utilise ICT to improve health services included the Electronic Patient Record (EPR) in independent, specific systems and the integrated, holistic record (EHR), which Information for Health (NHS Executive, 1998) aimed to deliver. The NHS Executive explained the important conceptual difference between the two:

Electronic Patient Record (EPR) describes the record of the periodic care provided mainly by one institution. Typically this will relate to the healthcare provided to a patient by an acute 
hospital. EPRs may also be held by other healthcare providers, for example, specialist units or mental health NHS Trusts.

The term Electronic Health Record (EHR) is used to describe the concept of a longitudinal record of patient's health and healthcare - from cradle to grave. It combines both the information about patient contacts with primary healthcare as well as subsets of information associated with the outcomes of periodic care held in the EPRs. (NHS Executive, 1998)

The approach and content of Information for Social Care were very different from the national infrastructure proposed for the National Health Service. For social care, the focus was to be on developments within individual local authorities, with far less central involvement, and no intention, at that stage, to develop national standards or infrastructural services. Capital grant money had been identified to support the initiative, and, as part of the conditions of receipt, local authorities were required to produce and publish a Local Implementation Plan, setting out their local strategies and evidencing how they would comply with the national approach. Integration with health partners was expected to take place at the local level, emerging from the work being undertaken to implement existing policy and practice initiatives (Department of Health, 2001).

Information for Social Care introduced an additional concept with regard to records, that of the Electronic Social Care Record (ESCR). The ESCR was intended to: provide a record that could be shared and accessed by service users or someone acting on their behalf; to enable the social care record to be used as a comprehensive individual record within social services; and to form the basis of the record that is shared with partner agencies (Social Care Information Policy Unit, 2003). One of the innovative features of this new approach was its emphasis on document management, and using it to support a holistic capture of an individual's case. For some authorities, the introduction of an EDMS (electronic document management system) took precedence over other requirements, while others looked to replace what they saw as outdated case management systems with newer, more strategically complementary ones. This work was not only being undertaken at the same time as the implementation of the National Service Framework for Older People, and its associated Single Assessment Process (SAP), but also coincided with the early piloting/roll-out of the Integrated Children's System. The attempt at an overarching strategy was both timely and welcome, even if a great many local authorities struggled to understand how the various pieces would fit together.

The Social Care Information Policy Unit (SCIPU), which produced Information for Social Care, was a group of policy advisors based within the Department of Health and responsible for national statistics relating to care. Shortly after the publication of the ESCR guidance in 2003, the resources of the SCIPU were absorbed into the newly created National Health System Information Authority (NHSIA). The NHSIA's primary focus was on Health developments, laying the foundations for NPfIT. The NHSIA was itself subsequently dissolved into a number of bodies in 2004, among which was the National Information Centre for Health and Social Care (NHS IC), which became responsible for collecting, collating and analysing health and care data. Another of the bodies that emerged from the dissolution of the NHSIA was Connecting for Health $(\mathrm{CfH})$, the organisation which took up the responsibility for delivering NPfIT. Social care was seen as outside the scope of the national programme, and while both the NHSIA and later the NHS IC continued to support the performance returns, the overall strategic 
direction and leadership that the SCIPU had provided was lost. This sidelining of the Information for Social Care policy created a number of issues, and the subsequent division of responsibility for adult and children's social care within local authorities added to the confusion.

Unsurprisingly, a number of local authorities saw the requirements for an ESCR as a low priority, and reduced or abandoned their developments. Work to integrate health and social care stuttered and lost momentum. System suppliers took the lead in translating the implications of policy into the design of technology, and local resources tended to be targeted at supporting the existing information structures (focused primarily on the production of performance information), rather than enabling new ways of working to emerge. This, in turn, limited the engagement of practitioners, who tended to see ICT systems as additional administrative burdens that reduced their contact with clients, rather than as a tool to support them in their day-to-day working. Much of the work done in Electronic Social Care Records has not been formally evaluated, so its success, or otherwise, is difficult to measure. This is in stark contrast to the extensive literature available concerning the implementation of electronic records in the health sector (Hartswood et al., 2003; Gans et al., 2005; Ludwick and Doucette, 2009), and the closely scrutinised progress of the NHS's national programme (Hendy et al., 2005; Coiera, 2007).

NPfIT, with a total investment estimated at $£ 12.6$ billion, was plagued by delays, contract disputes and increasing criticism from policy, practice, academia and the public (Cross, 2007, 2011; House of Commons Committee of Public Accounts, 2013). Some commentators have pointed out that, notwithstanding pronouncements of disaster, some elements of the programme were quite successful (Brennan, 2007). Thorough assessment of NPfIT is beyond the scope of this article. However, one significant theme that concerns us here is the techno-centric orientation of this massively ambitious large-scale project. Sponsors and managers seem to have assumed that technical deliverables developed in and for the private sector would transfer readily to intended users across the NHS. The centralised specification of system requirements allowed little involvement from local and front-line levels. Opposition successfully mounted by General Practitioners led to some mitigation of the top-down approach. By 2009, reports emerged of hospitals breaking away from the programme and putting in their own systems. Overall, there is evidence that, despite the top-down, techno-centric focus of NPfIT, some ad hoc innovation occurred at the local level to get the new systems to work or find alternatives (McLoughlin and Wilson, 2013).

The Coalition government that came to office in 2010 instigated a major review of government ICT structures and programmes. ContactPoint was discontinued, partially due to issues surrounding the rights to individual privacy. A consultation document entitled 'Liberating the NHS: an information revolution' was published late in 2010 and, following the response to that consultation, an information strategy was developed, with the intention of slimming down central control and enabling local choice (Department of Health, 2010, 2011). The Power of Information: Putting All of Us in Control of the Health and Care Information We Need, was published in May 2012, effectively announcing the end of the NPfIT (Department of Health, 2012). The emphasis on putting citizens in control encouraged local developments of citizen focused, integrated information services in order to support the envisioned restructuring of the NHS and further development of personalisation within social care. 


\section{Australia: developing ICT and transforming government}

In Australia, federal, state and territory governments share responsibility for the provision of health and social services. Changes proposed at the national level need to be negotiated with the states, where opposing political parties are often in power. As a result, Australia's systems of care tend to be more fragmented than in England. Federal government ICT policy in Australia since the mid-1990s has spanned multiple departments and focussed on procurement, outsourcing and support for the ICT industry. Before it lost office in 1996, the Labor federal government established an Information Technology Review Group 'to examine government acquisition and use of IT, and the formation of the Office of Government IT' (Aulich and Hein, 2005: 38). The Conservative Howard Government (1996-2007) also took an interest in using ICT, and set up the National Office of the Internet Economy (NOIE) in September 1997 to develop, oversee and coordinate Commonwealth government policy on 'electronic business, online services and the Internet' (Grant, 2002: 50). NOIE's priorities were largely economic, for example, helping to develop the ICT industry, although its goals also included 'transforming government information, services and administration through the use of ICT' (ibid.).

During the early 2000s, there was some shift in focus from the 'internet economy' to 'e-government'. The latter was more concerned with service delivery. Better Services, Better Government was launched in 2002 by the Minister for Communications, Information Technology and the Arts, Senator Richard Alston. The 'vision' outlined in this document included 'six key objectives: to achieve greater efficiency and a return on investment; to ensure convenient access to government services and information; to deliver services that are responsive to client needs; to integrate related services; to build user trust and confidence; and to enhance closer citizen engagement' (National Office of the Internet Economy, 2002: 25). In contrast to England, however, the integration and streamlining of social service delivery was not a major priority in ICT policy during this time.

As the 2000s progressed, the autonomy of agencies in Australia inhibited the development of 'joined up' services to engage citizens. Indeed the situation was even worse than this lack of connection, as agencies launched programmes that worked at cross purposes. For example, the following three attempts to use ICT to improve health services overlapped chronologically, and the lack of any clear relationships among them caused considerable confusion:

(a) Between 2000 and 2005, the Department of Health and Ageing worked on HealthConnect, a project that was supposed to provide a national system of interconnected electronic health records. This programme proved to be too ambitious and was downgraded to a 'change management' strategy (Fujitsu Consulting and Australian Government Department of Health and Ageing, 2004; Dearne, 2006a).

(b) While HealthConnect was still underway, Federal Health Minister, Tony Abbott, introduced a Medicare 'smart card', that would carry basic health information and was supposed to link in with the forthcoming HealthConnect. This card proved unpopular, with only 1 per cent registering during the trial period, and the plan was dropped (Dearne, 2006b).

(c) Before the Medicare smart card was dropped, the Department of Human Services initiated a 'National Services Access Card'. This card would be an individual's 'key to 
receiving Australian Government health and social services' (Ferguson, 2006). As well as holding information about identity and entitlements, there would be a capacity to customise the card so that it could hold a limited amount of health-related information, such as chronic illness status, immunisation information, allergies and organ donor status (Ferguson, 2006).

The relationship between the National Services Access Card, the Medicare Smart Card and the proposed HealthConnect was unclear. The National Services Access Card was particularly controversial. James Kelaher, head of the smartcard taskforce, resigned, warning that 'privacy and the confidence of those with a stake in the card, including the public, doctors, pharmacies, states and federal departments, were likely to be compromised by Human Services Minister Joe Hockey's proposed arrangements'. He urged the government to seek advice from independent experts (Grattan, 2006). A threemember Consumer and Privacy Taskforce was set up to address consumer and privacy issues. The Taskforce recommended some changes, and a Bill to enable the establishment of an access card was passed by the lower house of Parliament in February 2007. It did not pass the Senate, however, and was sent back for review. In June, as opposition to the scheme mounted, the government decided to delay the legislation. Labor announced that if it won the forthcoming election, the access card would be scrapped. Labor won, and the scheme was abandoned (Rossi, 2007; Dearne, 2007). There have been no further attempts to introduce smart cards in Australia for identification and service delivery.

The Labor government (2007-13) continued to promote e-government through the Australian Government Information Management Office (AGIMO) which took over from NOIE in 2004 (Australian Government Information Management Office, 2006; Smith, 2009). Labor also established a 'Government 2.0 Taskforce' to encourage the use of the 'collaborative web' to make government agencies 'more informed, responsive, innovative and citizen-centric' (Government 2.0 Taskforce, 2009: iii). There has been some integration of information systems. Citizens can now use the my.gov.au website to access a range of federal government benefits and services. One of these services is a 'personally controlled e-health record system', that was launched amid some controversy in 2012 (Garrety et al., forthcoming).

Away from the federal government, state government and community organisations have also developed ICT systems for use in social care. Examples include:

(a) The Looking After Children Electronic System (LACES), which aims to address the needs of children and young people receiving out-of-home care. This system developed out of a collaboration between Barnardos Australia, the University of New South Wales and the UK Department of Health (http://www.barnardos.org.au/ barnardos/html/lac_project.cfm).

(b) Supporting Children and Responding to Families (e-SCARF), a case management tool for Family Support services working with vulnerable families and children. This system was adapted from the United Kingdom (UK) Department of Health Framework for the Assessment of Children in Need and their Families (http://www.pdc.org.au/scarf).

(c) A Client Relationship Information System for Service Providers (CRISSP), another client and case management system, developed by the Victorian State Department of Human Services for use in the community services sector (http://www.dhs.vic.gov.au/ funded-agency-channel/information-technology/client-relationship-informationsystem-for-service-providers-crissp). 
(d) A range of systems and services available through Infoxchange Australia, a not-forprofit community organisation that delivers 'technology for social justice'. Infoxchange provides software applications, education and support for community organisations delivering social services, as well as service directories and a database of jobs available in the community sector (www.infoxchange.net.au).

As in England, there is a dearth of research and evaluation with regard to ICT for social care, but there are a few reports on the impact of these tools. The evidence suggests that their success to date has been limited, mainly because they are perceived by social care workers as failing to respond to their practice on the front line. A paper by Australian researchers published in 2008 noted that the use of ICT in child welfare in Australia, as in England, was 'embryonic'. They called on social workers to be more involved in design to ensure technology was developed to support care for clients rather than managerialist agendas (Tregeagle and Darcy, 2008). An empirical study of the use of the Client Relationship Information System for Service Providers (CRISSP) in the child welfare sector in Victoria found that the system was unwieldy and time-consuming. The author concluded that 'the system appears to impede rather than enhance service delivery' (Gillingham, 2011: 304).

\section{ICT for Health and social care in two countries}

Australia and the UK have significant differences in the organisation and delivery of their health and social care systems, but there is an on-going exchange of ideas between them. Both have followed broadly neoliberal welfare policies. National governments have invested heavily in electronic government over the last two decades, with some success. By 2003, the global consulting company Accenture summarised progress towards egovernment in twenty-two nations, and found Canada, Singapore and the US were the leaders. The report, however, judged that Australia was doing well in the development of e-government, in fifth position, somewhat ahead of the UK in eighth position (Accenture, 2003). The United Nations has since developed an influential e-government readiness index to assess aspects such as infrastructure development, on-line service availability, and the presence of appropriate human resources. In the latest iteration, the UK was placed third and Australia twelfth in e-government development out of 193 member states (United Nations, 2012).

In Australia and England, as in many other countries, policy makers expected that ICT and information services would support greater integration, information sharing and holistic views of patients/clients. The role of information has been positioned within debates about the performance management and accountability of health and social care providers. There has been a tendency to treat information as relatively unproblematic, and ICT as a magic box producing information that can be used to inform decisionmaking processes. While these are common themes, there are differences in emphasis. In Australia, central government interest in using ICT has been about building the economy and streamlining government, as well as improving services for citizens. In England, ICT has been enrolled for 'joining up' services perceived to be fragmented and prone to working in silos. This agenda is especially prominent in that country in relation to the longstanding and deeply embedded separation between health, under the NHS, and social care, as part of the responsibilities of local government. 
In both countries, conflicting views exist on privacy, confidentiality, and data access. Public and professional concerns over access to personal records, government surveillance and issues of data linking between services have, in some cases, influenced policy change, for example, in respect of smart cards in Australia and the national database of children in England. Yet the evidence is that the reality, far from the 'all-knowing panoptic state', has been 'a plethora of partial projects and initiatives that are seeking to harness ICTs in the service of better knowing and governing individuals and populations' (Ruppert, 2012: 318). Garrety et al. (this issue) examine Australian and English policy with regard to health care records. They explain the contested nature of patient consent, medical confidentiality and information management through the lens of 'moral orders', involving the personal and professional identities of all those involved from consumers to clinicians.

Complexities and tensions have been observed in Australia and in England in relation to national projects and centralised systems versus local developments and local requirements. There has been an oscillation of policy between centralisation and local ownership (and not always in synch). Division of responsibilities has led to separated projects and a lack of aligned vision, with spheres of e-government isolated in separate departments. Divisions of funding (national, departmental, local, and in Australia between federal and state entities) have led to differing priorities, conflicts in requirements and technologically incompatible solutions. This has been exacerbated as governments have increasingly encouraged a more diverse service supplier base, including small businesses, charities, social enterprises and community and voluntary organisations (Productivity Commission, 2010; Wilson et al., 2011). While policy has confidently promoted the idea of integrated, cross-sector systems and records, implementation has inevitably run into the realities of the multi-agency, mixed care economy, with its huge range in investment, development and implementation, and where the demands of delivery intersected uncomfortably with the strategic planning of national projects. Overall, no real balance has been found in either country between central control and local innovation.

\section{References}

Accenture (2003) E-government Leadership: Engaging the Customer, http://nstore.accenture.com/acn_ com/PDF/Engaging_the_Customer.pdf.

Australian Government Information Management Office (2006) e-Government Strategy, Responsive Government: A New Service Agenda, Parkes, ACT: AGIMO, http://www.finance.gov.au/publications/ 2006-e-government-strategy/docs/e-gov_strategy.pdf.

Ames, N. (1999) 'Social work recording: a new look at an old issue', Journal of Social Work Education, $35,2,227-38$.

Aulich, C. and Hein, J. (2005) 'Whole-of-government approaches to outsourcing and market testing by the Commonwealth government', Australian Journal of Public Administration, 64, 3, 35-45.

Brennan, S. (2007) 'The biggest computer programme in the world ever: how it's going', Journal of Information Technology, 22, 3, 202-11.

Cabinet Office (1999) Modernising Government, London: HMSO.

Cabinet Office (2005) Transformational Government: Enabled by Technology, London: HMSO.

Coiera, E. W. (2007) 'Lessons from the NHS National Programme for IT', The Medical Journal of Australia, $186,1,3-4$. 
Cornford, J., Wessels, B., Richardson, R., Gillespie, A., McLoughlin, I., Kohannejad, J., Belt, V. and Martin, M. (2003) Local e-Government: Process Evaluation of the Implementation of Electronic Local Government in England, London: ODPM.

Cross, M. (2007) 'Benefits of a £12bn programme are "unclear" MPs say', British Medical Journal, 334, 815.

Cross, M. (2011) 'Government announces end of NHS IT programme - for second time', British Medical Journal, 343, d6125.

Dearne, K. (2006a) "Changed vision" on health e-records', The Australian, 17 January.

Dearne, K. (2006b) 'Health smartcard fizzles', The Australian, 30 May.

Dearne, K. (2007) 'Canberra to cancel access card', The Australian, 27 November, http://www. australianit.news.com.au/story/0,24897,22823422-15306,00.html.

Department for Education and Skills (2003) Every Child Matters, London: HMSO.

Department of Health (2001) National Service Framework for Older People, London: Department of Health.

Department of Health (2010) Liberating the NHS: An Information Revolution, A consultation on proposals, London: Department of Health, http://www.ico.org.uk/about_us/consultations/ /media/documents/ consultation_responses/Liberating_the_NHS_An_Information_Revolution_Consultation.ashx.

Department of Health (2011) Liberating the NHS: An Information Revolution, A summary of consultation responses, London: Department of Health, https:/www.gov.uk/government/uploads/system/ uploads/attachment_data/file/216664/dh_129580.pdf.

Department of Health (2012) The Power of Information: Putting All of Us in Control of the Health and Care Information We Need, London: Department of Health, https:/www.gov.uk/government/publications/ giving-people-control-of-the-health-and-care-information-they-need.

Ferguson, I. (2006) 'An ID card by any other name?', ZDNet, 27 April, http://www.zdnet.com/ an-id-card-by-any-other-name-1139253868.

Fujitsu Consulting and Australian Government Department of Health and Ageing (2004) The HealthConnect Implementation Approach Version 1.0, Canberra: Australian Government Department of Health and Ageing.

Gans, D., Kralewski, J., Hammons, T. and Dowd, B. (2005) 'Medical groups' adoption of electronic health records and information systems', Health Affairs, 24, 5, 1323-33.

Garrety, K., McLoughlin, I., Wilson, R., Zelle, G. and Martin, M. (forthcoming) 'National electronic health records and the digital disruption of moral orders', Social Science and Medicine.

Gillingham, P. (2011) 'Computer-based information systems and human service organisations: emerging problems and future possibilities', Australian Social Work, 64, 3, 299-312.

Government 2.0 Taskforce (2009) Engage: Getting on with Government 2.0, Report of the Government 2.0 Taskforce, Parkes, ACT: AGIMO, http://www.finance.gov.au/publications/ gov20taskforcereport/doc/Government20TaskforceReport.pdf.

Grant, J. (2002) 'The National Office for the Information Economy: promoting government service delivery using new technologies', Canberra Bulletin of Public Administration, 104, 50-2.

Grattan, M. (2006) 'Smartcard chief resigns', The Age, 9 May, http://www.theage.com.au/news/ national/smartcard-chief-resigns/2006/05/08/1146940479804.html.

Hartswood, M., Procter, R., Rouncefield, M. and Slack, R. (2003) 'Making a case in medical work: implications for the electronic medical record', Computer Supported Cooperative Work (CSCW), $12,3,241-66$.

Haux, R., Ammenwerth, E., Herzog, W. and Knaup, P. (2002) 'Health care in the information society: a prognosis for the year 2013', International Journal of Medical Informatics, 66, 1-3, 3-21.

Hendy, J., Reeves, B. C., Fulop, N., Hutchings, A. and Masseria, C. (2005) 'Information in practice: challenges to implementing the national programme for information technology (NPfIT)', British Medical Journal, 331.

House of Commons Committee of Public Accounts (2013) The Dismantled National Program for IT in the NHS, London: The Stationery Office. 
Ludwick, D. and Doucette, J. (2009) 'Adopting electronic medical records in primary care: lessons learned from health information systems implementation experience in seven countries', International Journal of Medical Informatics, 78, 1, 22-31.

McCoy, H. V. and Vila, C. K. (2002) 'Tech knowledge: introducing computers for coordinated care', Health and Social Work, 27, 1, 71-4.

McLoughlin, I. and Wilson, R. (2013) Digital Government at Work, Oxford: Oxford University Press.

National Office of the Internet Economy (2002) Better Services, Better Government, Canberra: NOIE.

NHS Executive (1998) Information for Health: An Information Strategy for the Modern NHS 1998-2005: A National Strategy for Local Implementation, London: Department of Health.

Productivity Commission (2010) Contribution of the Not-For-Profit Sector, Canberra: Productivity Commission.

Rossi, S. (2007) 'Labor to dump billion dollar Access card if it wins federal election', CIO, 16 October, http://www.cio.com.au/article/197344/labor_dump_billion_dollar_access_card_it_wins_federal_ele ction?eid=-601.

Ruppert, E. (2012) 'The governmental topologies of database devices', Theory Culture Society, 29, 4/5, $116-36$.

Smith, R. F. I. (2009) Organizing for E-government: In Search of Effective ICT Governance in Australia, Melbourne: Monash University.

Social Care Information Policy Unit (2001) Information for Social Care, London: Department of Health.

Social Care Information Policy Unit (2003) Defining the Electronic Social Care Record, London: Department of Health.

Steyaert, J. and Gould, N. (1999) 'Social services, social work, and information management: some European perspectives', European Journal of Social Work, 2, 2, 165-75.

Tregeagle, S. and Darcy, M. (2008) 'Child welfare and information and communication technology: today's challenge', British Journal of Social Work, 38, 8, 1481-98.

United Nations (2012) E-government Survey 2012: E-government for the People, New York: United Nations.

Wilson, R., Baines, S., Cornford, J. and Martin, M. (2007) 'Trying to do a jigsaw without the picture on the box: understanding the challenges of care integration in the context of single assessment for older people in England', International Journal of Integrated Care, 7, http://www.ijic.org/index.php/ijic/article/ view/URN\%3ANBN\%3ANL\%3AUI\%3A10-1-100428/371.

Wilson, R., Martin, M., Walsh, S. and Richter, P. (2011) 'Re-mixing the digital economies of care in the voluntary and community sector (VCS): governing identity and information sharing in the mixed economy of care for children and young people', Social Policy and Society, 10, 3, 379-91. 